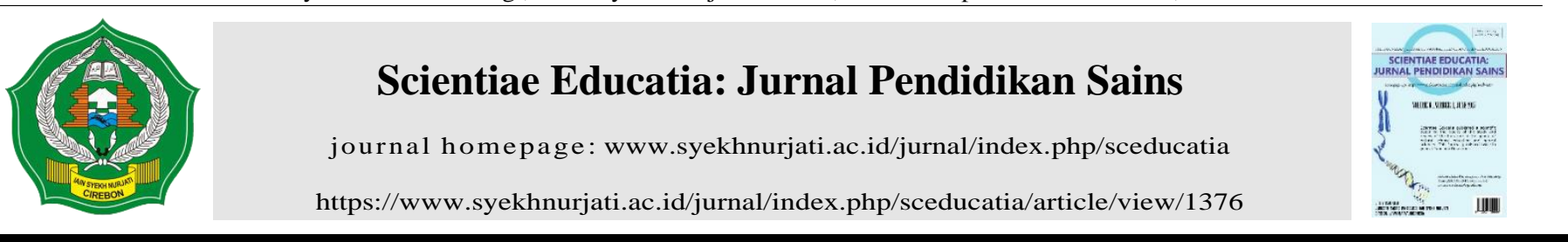

\title{
Penguasaan Mahasiswa Calon Guru Biologi Terhadap Representasi Visual Dalam Botani Phanerogamae
}

\author{
Asep Mulyani \\ Jurusan Tadris IPA Biologi, IAIN Syekh Nurjati Cirebon, Jawa Barat, 45132, Indonesia \\ *Corresponding author: Jalan Perjuangan Bypass, Sunyarangi, Kesambi, Kota Cirebon, Jawa Barat 45132, Indonesia. E-mail addresses: asepm47@gmail.com
}

a r t c l e i n f o

Article history:

Received 28 February 2017

Received in revised form 16 June

2017

Accepted 16 June 2017

Available online June 2017

Keywords:

biology teacher candidate

visual representation

botani phanerogamae

Kata Kunci:

calon guru biologi

representasi visual

botani phanerogamae

\author{
a b s t r a c t
}

\begin{abstract}
This study aims to determine the mastery of biology candidate teacher students to visual representation in phanerogamae botanical courses. Teachers must have the ability in the mastery of visual representation that is used as a tool to clarify the material to be delivered on learning activities. Therefore, the ability of prospective biology teacher students to visual representation should be good so that by the time it becomes a teacher can provide quality biology learning. The research method used is descriptive quantitative research method. The population is a biology teacher candidate who has attended phanerogamae botany lecture in 2016 in four classes. The sample is taken one class. The instrument used is a multiple choice test. The results showed that the ability of biology teacher candidates to master visual representation in a phanerogamae botanical course is the average score of 45.31. It was concluded that the mastery of biology teacher candidates in the mastery of visual representation is low. The mastery of visual representation is influenced by visual literacy, the scope of matter, the level of material representation, and the type of visual representation.
\end{abstract}

\begin{abstract}
Penelitian ini bertujuan untuk mengetahui penguasaan mahasiswa calon guru biologi terhadap representasi visual dalam mata kuliah botani phanerogamae. Guru harus mempunyai kemampuan dalam penguasaan representasi visual yang digunakan sebagai alat untuk memperjelas materi yang akan disampaikan pada kegiatan belajar pembelajaran. Oleh karena itu, kemampuan mahasiswa calon guru biologi terhadap representasi visual harus baik agar pada saat sudah menjadi guru dapat memberikan pembelajaran biologi yang berkualitas. Metode penelitian yang digunakan adalah metode penelitian deskriptif kuantitatif. Populasinya adalah mahasiswa calon guru biologi yang telah mengikuti perkuliahan botani phanerogamae di tahun 2016 sebanyak empat kelas. Sampel yang diambil satu kelas. Instrumen yang digunakan adalah tes pilihan ganda. Hasil penelitian menunjukan jika kemampuan mahasiswa calon guru biologi dalam menguasai representasi visual dalam mata kuliah botani phanerogamae yaitu nilai rata-ratanya 45,31. Disimpulkan bahwa penguasaan mahasiswa calon guru biologi dalam penguasaan representasi visualnya rendah. Penguasaan representasi visual dipengaruhi oleh literasi visual, ruang lingkup materi, tingkat representasi materi, dan tipe representasi visual.
\end{abstract}

2017 Scientiae Educatia: Jurnal Pendidikan Sains

\section{Pendahuluan}

Pembelajaran merupakan proses terjadinya interaksi aktif antara guru dengan siswa untuk mencapai tujuan pembelajaran yang telah direncanakan. Guru mempunyai peran strategis karena harus dapat menguasai materi yang akan diajarkan sekaligus menguasai bagaimana cara menyampaikan materi (Shulman, 1986). Siswa akan mendapatkan pembelajaran yang berkualitas apabila diajar oleh guru yang menguasai dua kemampuan tersebut.

Harlen (1997) mengemukakan bahwa penguasaan konsep guru sains akan berpengaruh terhadap pembelajaran di kelas. Guru yang menguasai materi diajarkan akan lebih percaya diri dibandingkan dengan guru yang tidak menguasai materi ajar. Penguasaan materi ajar yang baik akan memudahkan guru dalam memilih strategi pembelajaran yang tepat.

Proses belajar dan pembelajaran biologi harus didukung oleh kemampuan guru dalam menguasai materi biologi. Materi biologi yang diajarkan harus dimudah dipahami oleh siswa dengan mempertimbangkan karakteristik materi ajar yang akan disampaikan di dalam pembelajaran biologi. Tsui \& Treagust(2013) mengemukakan tentang tingkat representasi materi biologi, yaitu: 1) makroskopis; 2) mikroskopis; 3) submikroskopis; dan 4) simbolik.

Perkembangan penelitian dalam bidang biologi menyebabkan konsep-konsep dalam biologi menjadi semakin komplek dan abstrak. Peneliti banyak menggunakan representasi visual agar dapat mengkomunikasikan hasil penelitiannya melalui berbagai publikasi ilmiah (Richards, 2003). Gooding (2004) mengemukakan bahwa masyarakat ilmiah berkomunikasi dan menyampaikan pengetahuan baru dengan menggunakan representasi. Representasi visual merupakan salah satu cara 
penyampaian informasi agar dapat diterima dengan baik oleh penerima informasi. Griffard(2013) mengemukakan bahwa proses komplek yang terjadi dalam biologi dapat di sampaikan dalam bentuk diagram.

Representasi visual dalam biologi dapat disajikan dengan menggunakan berbagai bentuk visualisasi, misalnya, photo, gambar, tabel, bagan, diagram, dan lainnya.Vinisha \& Ramadas (2013) mengemukakan jika representasi visual memudahkan dalam memahami konsep yang abstrak. Guru yang menggunakan representasi harus mempunyai kemampuan penguasaan konsep dan keterampilan literasi visual dengan baik agar dapat menyampaikan materi secara efektif dan efisien.

Literasi visual merupakan kemampuan dalam mengkomunikasikan pengetahuan melalui perumpamaan(Bell, 2014), biasanya dalam bentuk gambar. Biologi banyak menggunakan visualisasi dalam menjelaskan konsep atau fenomena yang terjadi mulai dari tingkat makroskopis ataupun simbolik. Literasi visual mempunyai peranan yang sangat penting dalam pembelajaran biologi khususnya biokimia(Schonborn \& Anderson, 2006).

Kemampuan guru dalam memahami representasi harus sudah disiapkan sejak masih menjadi mahasiswa calon guru. Calon guru biologi khususnya, harus mempunyai kemampuan dalam menguasai representasi visual yang menyajikan konsep-konsep biologi yang komplek dan rumit. Representasi dapat menyederhanakan cara penyampaian materi sehingga mudah dipahami dan mengurangi terjadinya miskonsepsi pada siswa.

Mahasiswa calon guru biologi harus menguasai konsep-konsep biologi yang disajikan secara visual. Visualisasi dapat memberikan kemudahan bagi mahasiswa dalam menguasai materi sehingga pada saat sudah menjadi guru dapat menyampaikan materi biologi dengan baik pada siswanya. Perkembangan informasi khususnya dalam bidang biologi akan memberikan dampak pada semakin komplek dan rumitnya materi biologi yang harus dikuasai oleh guru atau calon guru biologi.

Mahasiswa calon guru biologi yang mengambil mata kuliah botani, sebaiknya menguasai representasi visual yang digunakan dalam menjelaskan konsep-konsep yang komplek dalam botani. Mulyani (2014) menyatakan bahwa materi tumbuhan banyak menggunakan representasi visual dalam buku biologi SMA untuk memberikan penjelasan kepada siswa. Kladogram banyak ditemukan dalam buku-buku biologi sekolah menengah ataupun perkuliahan sejak awal tahun 1990 -an yang digunakan untuk menjelaskan hubungan evolusi organisme (Catley \& Novick, 2008).

Kemampuan menguasai representasi merupakan faktor penting dalam mengajarkan materi biologi karena akan dapat menyampaikan materi yang komplek dengan cara yang lebih sederhana. Visualisasi akan menyederhanakan cara penyajian sehingga penjelasan yang diberikan oleh guru akan lebih efektif dan siswa akan lebih mudah memahami materi tersebut. Penguasaan terhadap materi yang direpresentasikan akan memberikan kemudahan bagi guru pada saat menjelaskan materi di kelas.

Guru biologi harus mampu memahami dan menginterpretasikan gambar yang digunakan untuk menjelaskan konsepkonsep. Liu, et all. (2014) mengemukakan bahwa guru biologi dapat mengembangkan beragam diagram dalam mengajarkan konsep biologi. Kemampuan dalam menguasai representasi akan memperkaya cara dan kemampuan dalam menjelaskan materi biologi pada saat pembelajaran di kelas. Mahasiswa calon guru biologi harus mempunyai kemampuan yang baik dalam mengkomunikasikan representasi konsep-konsep biologi agar pembelajaran dapat berlangsung secara efektif dan efisien.

Kemampuan mahasiswa calon guru biologi dalam menguasai representasi visual khususnya dalam mata kuliah botani harus diidentifikasi sejak awal agar memudahkan pembelajaran. Representasi yang baik tidak akan berarti apabila yang tidak tahu cara memahami representasi tersebut. Penguasaan terhadap representasi visual membutuhkan keterampilan dan pembiasaan visual yang baik.

Buku-buku teks biologi banyak menyajikan representasi visual dalam penyajian konsep-konsep biologi. Representasi yang disajikan seiring dengan perkembangan pengetahuan yang banyak dipublikasikan melalui jurnal-jurnal internasional sehingga memperkaya informasi yang sudah ada. Penelitian dalam bidang biologi sering menyajikan gambar atau diagram dalam menjelaskan hasil penelitiannya.

Ainsworth (2008) mengemukakan bahwa pembelajaran dapat didukung dengan menggunakan kombinasi beberapa representasi visual mempunyai peran yang sangat penting. Materi biologi harus dapat disajikan dengan sederhana dan mudah dipahami oleh siswa melalui visualisasi yang tepat. Visualisasi yang baik akan memberikan kemudahan bagi guru dalam menyampaikan materi biologi. Guru menyajikan menjelaskan konsep-konsep abstrak dengan cara yang lebih konkret agar informasi yang disampaikan lebih efektif. Representasi dalam bentuk gambar atau diagram dapat menjadi salah satu alat yang digunakan oleh guru dalam pembelajaran biologi di kelas.

Mahasiswa Tadris IPA Biologi IAIN Cirebon sebagai calon guru biologi harus diidentifi kasi kemampuan dalam menguasai representasi visual. Oleh karena itu, maka peneliti akan mengidentifikasi penguasaan mahasiswa calon guru biologi terhadap representasi visual dalam mata kuliah Botani Phanerogamae.

\section{Metode Penelitian}

Metode penelitian yang digunakan dalam penelitian ini adalah metode deskriptif kuantitatif. Populasinya adalah mahasiswa calon guru biologi semester 5 sebanyak empat diambil satu kelas sebanyak 32 mahasiswa sebagai sampelnya. Instrument test yang digunakan merupakan hasil pengembangan peneliti yang bertujuan untuk mengidentifikasi penguasaan mahasiswa calon guru biologi terhadap representasi visual dalam perkuliahan botani.

Penguasaan representasi visual dalam penelitian ini difokuskan pada tiga aspek menurut Tsui \& Treagust (2013) yang disesuaikan dengan keperluan penelitian, yaitu: 1) ruang lingkup materi mencakup materi inti, yang terdiri dari sistematik, fitografi, reproduksi tumbuhan, dan klasifikasi tumbuhan berbiji; 2) tingkat representasi materi, yang terdiri dari tingkat 
makroskopis dan simbolik(materi atau konsep abstrak); 3) tipe representasi visual, yang terdiri dari photo, gambar, diagram, diagram skematik, kladogram, dan simbolik(simbol atau persamaan). Test dalam bentuk pilihan ganda berbasis representasi visual sebanyak 50 soal. Setiap soal selalu ada gambar sebagai dasar dari pertanyaan. Soal tersebut kemudian diuji coba dan hasilnya 40 soal yang valid, dan mempunyai reliabilitas yaitu 0.92 .

Data yang diperoleh dideskripsikan berdasarkan hasil perolehan nilai test penguasaan representasi visual. Penguasaan representasi visual mahasiswa calon guru biologi dianalisis berdasarkan ruang lingkup materi, tingkat representasi materi, dan tipe representasi visualnya. Penelitian dilaksanakan di Jurusan Tadris IPA Biologi IAIN Syekh Nurjati Cirebon.

\section{Hasil dan Pembahasan}

Hasil penelitian penguasaan representasi visual mahasiswa calon guru biologi berdasarkan ruang lingkup materi, tingkat representasi materi, dan tipe representasi visualnya. Penguasaan representasi visual mahasiswa berdasarkan ruang lingkup materi, terdiri dari: sistematik, fitografi, proses reproduksi tumbuhan, dan klasifikasi tumbuhan berbijinya. Nilai rata-rata total penguasaan representasi visual mahasiswa calon guru biologi adalah 45,31.

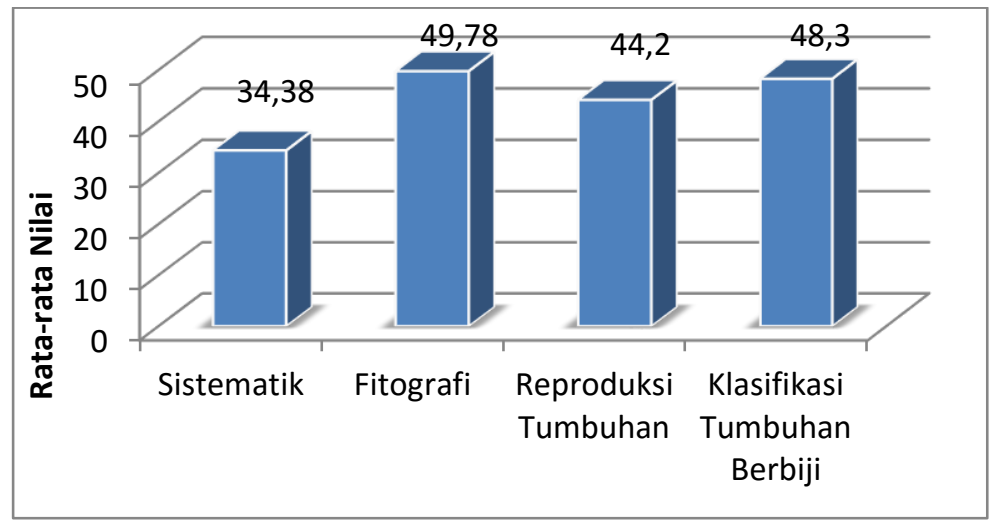

Gambar 1. Rata-rata nilai kemampuan mahasiswa calon guru biologi dalam menguasai representasi visual berdasarkan materi pokoknya.

Berdasarkan Gambar 1, rata-rata nilai penguasaan representasi visual mahasiswa calon guru biologi berdasarkan ruang lingkup materi pokoknya secara berturut-turut adalah nilai rata-rata nilai tertinggi pada materi fitografi yaitu 49,78, klasifikasi tumbuhan berbiji yaitu 48,3, reproduksi tumbuhan yaitu 44,2, dan rata-rata nilai terendah pada materi sistematik yaitu 34,38 .

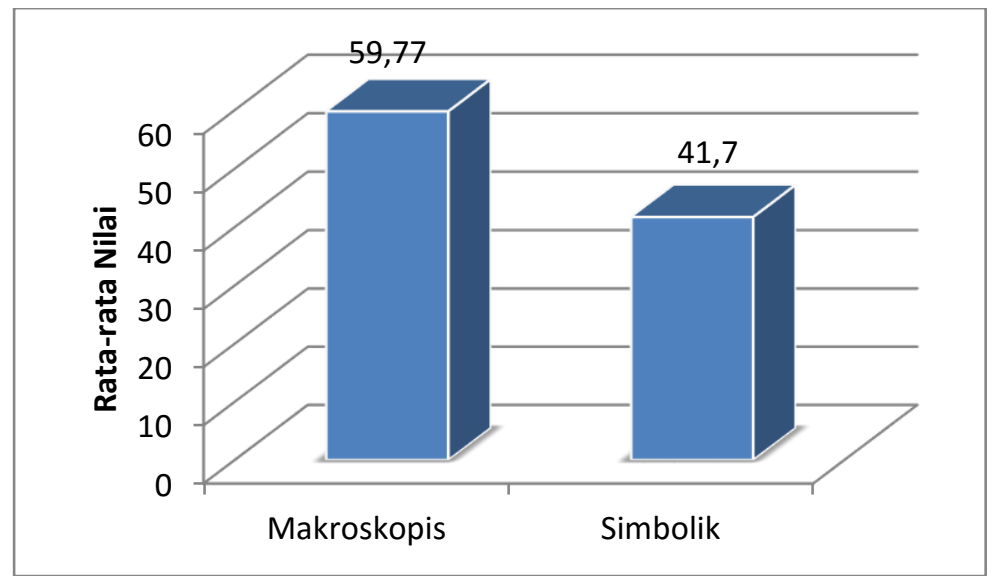

Gambar 2. Rata-rata nilai kemampuan mahasiswa calon guru biologi dalam menguasai representasi visual berdasarkan tingkat representasi materi.

Berdasarkan Gambar 2, rata-rata nilai penguasaan representasi visual mahasiswa calon guru biologi berdasarkan tingkat representasi materi secara berurutan adalah rata-rata nilai tertinggi pada level makroskopis yaitu 59,77 dan rata-rata nilai terendah pada level simbolik yaitu 41,70. 


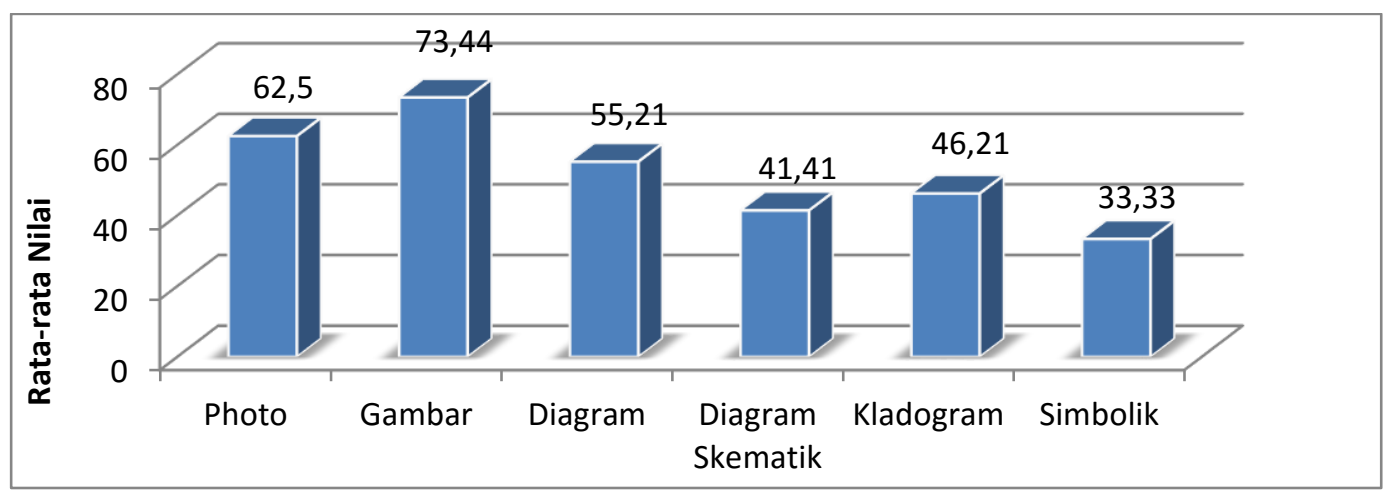

Gambar 3. Perbandingan rata-rata nilai kemampuan mahasiswa calon guru biologi dalam menguasai representasi visual berdasarkan tipe representasi visualnya.

Berdasarkan Gambar 3, rata-rata nilai penguasaan representasi visual mahasiswa calon guru biologi berdasarkan tipe representasi visualnya secara berturut-turut adalah nilai rata-rata nilai tertinggi pada tipe gambar yaitu 73,44, photo yaitu 62,5 , diagram yaitu 55,21, Kladogram yaitu 46,21, diagram skematik yaitu 41,41, dan rata-rata nilai terendah pada tipe simbolik yaitu 33,33. Tipe simbolik pada gambar 3 dimaksudkan untuk menunjukan tipe representasi visual yang digunakan dalam soal, sedangkan pada gambar 2 ditujukan untuk menunjukan tingkat representasi materinya.

Secara umum, hasil penelitian menunjukan bahwa penguasaan mahasiswa calon guru biologi masih rendah. Penguasaan representasi visual calon guru biologi dideskripsikan berdasarkan tiga aspek, yaitu: ruang lingkup materi, tingkat represent asi materi, dan tipe representasi visualnya.

Berdasarkan ruang lingkup materinya, penguasaan mahasiswa terhadap representasi visual paling rendah pada sistematik dan paling bagus penguasaannya pada fitografi. Penguasaan mahasiswa yang rendah terhadap materi sistematik dipengaruhi oleh jenis konsepnya yang abstrak, sedangkan pada materi fitografi berifat konkret. Jenis materi yang abstrak akan memberikan kesulitan tersendiri bagi mahasiswa karena membutuhkan kemampuan dalam menginterpretasikan yang tinggi dalam memahaminya.

Materi reproduksi tumbuhan merupakan materi yang terendah kedua dikuasai oleh mahasiswa. Reproduksi tumbuhan sulit dipahami karena banyak menyajikan proses yang komplek dan kurang terbiasa mahasiswa dalam memahami visualisasi yang disajikan. Materi yang melibatkan proses yang komplek lebih sulit dipahami dibandingkan dengan konsep yang hanya berupa fakta atau konsep konkret. Konsep yang abstrak menyulitkan mahasiswa calon guru menguasai materi reproduksi tumbuhan.

Klasifikasi tumbuhan merupakan materi yang terendah ketiga dikuasai oleh mahasiswa calon guru biologi. Mahasiswa mengalami kesulitan dalam menguasai representasi visual yang berkaitan dengan klasifikasi karena visualisasi yang disajikan sangat abstrak. Klasifikasi seiring dengan banyaknya hasil penelitian dalam bidang ini menjadi konsep yang komplek dan rumit untuk dipelajari.

Mahasiswa calon guru biologi lebih menguasai representasi visual untuk fitografi dibandingkan dengan konsep-konsep yang lainnya. Fitografi menyajikan banyak fakta yang konkret sehingga mudah dipahami. Jenis konsep yang mudah dipahami dan visualisasi yang baik memberikan kemudahan bagi mahasiswa dalam menguasai materi ini. Penguasaan representasi pada materi fitografi yang lebih baik disbanding dengan materi lainnya, tetapi masih rendah apabila dibandingkan dengan nilai maksimal yang dapat diperoleh.

Aspek yang kedua, di analisis berdasarkan tingkat representasi materi. Level makroskopis lebih dikuasai oeh mahasiswa calon guru biologi dibandingkan dengan yang lainnya. Level makroskopis mudah dipahami karena berkaitan dengan jenis konsep yang konkret. Level mikroskopis lebih sulit dikuasai karena banyak berkaitan dengan jenis konsepnya yang abstrak sehingga menyulitkan mahasiswa dalam menguasainya.

Aspek yang ketiga, yaitu berdasarkan tipe representasi visualnya. Mahasiswa calon guru biologi kesulitan dalam memahami tipe representasi visual simbolik. Visualisasi yang abstrak membuat mahasiswa harus mempunyai kemampuan yang tinggi terkait literasi visualnya. Penguasaan mahasiswa terhadap tipe representasi meningkat seiring dengan semakin konkretnya tipe representasi yang disajikan dalam soal.

Tipe simbolik dalam mata kuliah botani digunakan untuk menjelaskan konsep-konsep yang abstrak dengan tujuan untuk lebih menyederhanakan konsep yang sedang disampaikan. Konsep yang abstrak dan disajikan secara abstrak masih menjadi kesulitan mahasiswa dalam menguasai materi biologi. Usaha yang tinggi masih tetap diperlukan oleh mahasiswa agar dapat menguasai materi yang abstrak tersebut.

Tipe representasi terendah kedua penguasaan oleh mahasiswa calon guru biologi, yaitu tipe diagram skematik. Proses atau mekanisme yang terjadi banyak divisualisasikan dengan menggunakan diagram skematik. Diagram skematik memberikan penjelasan secara lebih rinci dan jelas sehingga dapat memberikan kemudahan dalam memahami materi yang disajikan. Tahapan-tahapan dari suatu peristiwa disajikan secara bertahap untuk memberikan gambaran yang utuh terhadap konsep yang sedang dijelaskan.

Biologi mempunyai banyak proses komplek (Griffard, 2013) dan mekanisme dalam menjelaskan fenomena alam. Proses tersebut tentunya akan melibatkan banyak konsep yang komplek dan rumit sehingga dalam penyampaiannya harus tepat supaya 
tidak terjadi miskonsepsi. Materi yang komplek dan rumit tentunya membutuhkan visualisasi yang cukup rumit akan membuat kita memerlukan energi yang lebih besar supaya dapat memahaminya.

Diagram skematik merupakan salah satu tipe representasi yang dapat digunakan untuk menyajikan serangkaian proses yang yang terjadi dalam alam agar mudah dipahami. Penguasaan mahasiswa terhadap representasi visual akan mengalami kesulitan apabila konsep yang disajikan merupakan konsep yang abstrak. Oleh karena itu, pemilihan representasi visual untuk konsep yang abstrak harus betul-betul dipilih secara tepat dengan mempertimbangkan karakteristik materi atau jenis konsepnya.

Tipe representasi visual terendah ke tiga yang dikuasai oleh mahasiswa calon guru biologi yaitu kladogram. Evolusi tumbuhan banyak divisualisasikan dengan menggunakan kladogram. Hubungan kekerabatan antar tumbuhan yang satu dengan tumbuhan yang lainnya dapat dipahami melalui kladogram. Kesulitan mahasiswa dalam menguasai konsep yang direpresentasikan melalui kladogram tentunya selain karena konsepnya, ternyata mahasiswa belum terbiasa dalam memahami representasi dan kemampuan literasi visualnya yang masih rendah.

Evolusi tumbuhan dalam mata kuliah botani, merupakan kajian yang komplek dan rumit sehingga membutuhkan representasi yang tepat dalam penyajiannya. Penguasaan mahasiswa dalam menguasai representasi yang disajikan sangat dipengaruhi oleh tingkat literasi visual dan penguasaan konsep yang direpresentasikan.konsep yang abstrak dan rumit tentaunya akan membutuhkan representasi yang abstrak dan rumit juga.

Kesulitan mahasiswa dalam mengabstraksi suatu konsep tentunya akan berpengaruh terhadap kemampuannya dalam menguasai materi tersebut. Mahasiswa harus mampu mengembangkan literasi visualnya agar dapat dengan mudah memahami konsep yang sedang direpresentasikan karena pada hakekatnya reperesentasi menyederhanakan konsep yang sulit dipahami.

Kladogram merupakan bagian dari jenis diagram. penelitian ini memisahkan kladogram agar lebih memperjelas peran kladogram dalam merepresentasikan materi yang harus dikuasai. Kladogram merupakan bentuk diagram yang khas biasa digunakan dalam biologi khusunya pada saat menjelaskan evolusi organisme agar mudah dipahami. Kemampuan literasi visual yang tinggi diperlukan agar dapat memahami konsep yang direpresentasikan secara visual.

Kladogram mempunyai peranan yang penting dalam buku teks biologi (Halverson \& Friedrichsen, 2013) sebagai alat dalam pembelajaran biologi (Catley \& Novick, 2008). Kladogram berfungsi sebagai alat yang cukup efektif dalam menjelaskan evolusi makhluk hidup sekaligus dapat memberikan penjelasan terkait dengan kedudukan organisme tersebut dalam taksonomi. Interpretasi terhadap kladogram akan membuat kita lebih memahami tentang hubungan kekerabatan antar organisme yang mempunyai peran penting dalam penguasaan konsep-konsep biologi selanjutnya.

Tipe representasi yang penguasaannya rendah ke empat yaitu tipe diagram. Diagram yang dimaksud disini merupakan tipe diagram yang sederhana yang digunakan untuk memperjelas struktur bunga atau bagian tumbuhan yang lainnya. Penggunaan diagram secara tepat dalam tumbuhan akan memberikan kemudahan dalam memahami struktur tumbuhan. Penjelasan berkenaan dengan bagian dan letak secara tepat dan akurat dapat direpresentasikan dengan menggunakan diagram sehingga tidak terjadi miskonsepsi.

Guru biologi dapat mengembangkan beragam diagram dalam mengajarkan konsep biologi (Liu, et all., 2014) agar memudahkan siswa dalam memahami materi. Pertimbangan dalam memilih bentuk diagram yang tepat akan sangat penting untuk menyampaikan konsep dalam biologi agar tidak kehilangan makna dengan bentuk representasi tersebut.

Representasi visual digunakan oleh guru biologi dalam pembelajaran agar materi yang mudah disampaikan dan dipahami oleh siswa. Mahasiswa calon guru biologi harus menguasai representasi visual dengan baik agar dapat dengan mudah memberikan penjelasan materi pada saat sudah menjadi guru. Kemampuan literasi visual yang dimiliki oleh mahasiswa calon guru biologi harus terus dikembangkan.

Tipe representasi yang penguasaannya paling baik yaitu photo. Representasi yang mendekati objek aslinya yaitu photo. Gambar yang ditampilkan melalui photo memberikan informasi secara lebih baik dan mudah dipahami disbanding dengan representasi visual yang lainnya. Gambar objek yang mendekati yang sebenarnya tidak akan membutuhkan energi yang banyak dalam usaha memahaminya.

Photo merupakan bentuk visualisasi yang sebenarnya akan memberikan kemudahan dalam memahaminya. Buku teks biologi banyak menggunakan photo sebagai bagian dari usaha agar memudahkan pembaca dalam menangkap informasi yang sedang disajikan. Kita akan lebih mudah memahami objek berupa photo dibandingkan dengan bentuk representasi yang lainnya. Buku biologi banyak menggunakan representasi bentuk photo yang berperan penting dalam interpretasi siswa untuk memahami materi yang disampaikan(Roth, et all, 2005).

Representasi visual berupa gambar merupakan tipe representasi yang paling dikuasai oleh mahasiswa calon guru. Gambar mudah dipahami karena selain mendekati aslinya, tetapi juga dapat memberikan penjelasan secara lebih detail terkait bagian atau struktur tumbuhan yang sedang dijelaskan. Tumbuhan banyak digambarkan secara lebih detail karena fleksibilitas gambar yang secara nyata dapat menunjukan bagian-bagian yang tidak dapat ditunjukan melalui photo.

Pemahaman konseptual melalui bahasa verbal dan teks akan memberikan pengalaman yang kaya bagi siswa(Philips, et all., 2010). Keberhasilan belajar siswa akan dipengaruhi oleh pengalaman belajarnya. Bahasa teks dan verbal akan memudahkan siswa dalam menerima informasi yang penting pada saat pembelajaran. Daya tarik akan meningkat apabila kita menggunakan teks dan gambar dalam menjelaskan materi atau konsep yang rumit.

Representasi salah satu fungsinya adalah memberikan daya tarik terhadap materi atau konsep yang sedang disampaikan. Daya tarik ini merupakan faktor penting dalam keberhasilan pembelajaran karena siswa akan termotivasi untuk memberikan 
perhatian terhadap representasi tersebut. Secara visual, objek yang disampaikan secara menarik akan membuat orang yang melihatnya berusaha untuk memahami objek tersebut.

Sains mempunyai bahasa tersendiri dengan menggunakan teks atau gambar secara visual untuk memvisualisaikan informasi yang akan disampaikan (Anagnostopoulou, et all 2012). Biologi menggunakan bahasa dengan menggunakan teks dan gambar untuk menjelaskan materi yang komplek dan rumit dengan cara yang sederhana. Visualisasi memberikan kemudahan bagi dalam cara penyampaian pesan atau informasi.

Masyarakat ilmiah menurut Gooding (2004), berkomunikasi dan menyampaikan pengetahuan baru dengan menggunakan representasi. Hasil penelitian akan dipublikasikan dengan menggunakan representasi dengan didukung oleh argumen yang menjelaskan hasil penelitian tersebut. Representasi berupa teks atau gambar secara visual memberikan kemudahan bagi para ilmuwan dalam mengkomunikasikan hasil penelitiannya.

Pembelajaran dapat didukung dengan menggunakan kombinasi beberapa representasi visual mempunyai peran yang sangat penting(Ainsworth, 2008). Representasi merupakan cara yang sederhana dalam berkomunikasi dalam menyampaikan konsepkonsep biologi di kelas agar mudah dikuasai oleh siswa. Kemampuan mahasiswa calon guru biologi dalam menguasai representasi visual akan berpengaruh pada kualitas pembelajaran pada saat mereka sudah menjadi guru.

Mahasiswa calon guru biologi yang masih rendah penguasaan representasi visualnya akan berdampak pada kemampuannya dalam menjelaskan materi. Penguasaan representasi visual mahasiswa calon guru biologi khususnya pada mata kuliah botani phanerogamae sangat dipengaruhi oleh kemampuan literasi visualnya. Literasi visual mahasiswa calon guru biologi yang masih rendah dapat ditingkatkan dengan cara memberikan pembiasaan pada mereka khususnya pada saat perkuliahan berlangsung.

Perkuliahan yang banyak memberikan banyak aktivitas yang berhubungan dengan gambar akan memberikan pengaruh terhadap hasil belajarnya. Perkuliahan dapat diberikan dengan banyak menyajikan visualisasi untuk meningkatkan keterampilan literasi visualnya(Bell, 2014). Konsep-konsep dapat disajikan dengan menggunakan kombinasi beberapa tipe representasi dapat meningkatkan kemampuan mahasiswa dalam meningkatkan literasi visualnya.

Representasi visual yang digunakan dalam perkuliahan botani phanerogamae dapat menggunakan beragam representasi sesuai dengan karakteristik materinya. Tipe representasi visual yang dapat digunakan dalam perkuliahan botani phanerogame berdasarkan materinya yaitu materi sistematik tumbuhan bisa menggunakan kladogram untuk membantu menjelaskan hubungan evolusi dari setiap takson pada tumbuhan, materi fitografi sebaiknya menggunakan photo atau gambar, materi reproduksi tumbuhan sebaiknya menggunakan diagram skematik untuk menjelaskan prosesnya, dan klasifikasi tumbuhan dapat menggunakan diagram, tabel, dan gambar.

Representasi berfungsi dalam pembelajaran dengan berbagai cara, yaitu sebagai proses, sebagai klaims, produk, dan sebagai alat(Prain \& Tytler, 2013). Pertama, secara proses merupakan fungsi representasi sebagai sumber persepsi yang menggambarkan, memvisualisasikan, menguji, mengkomfirmasi dan alasan. Kedua, sebagai Klaims merupakan representasi yang berfungsi dalam menggambarkan fakta-fakta sejumlah fenomena. Ketiga, sebagai produk merupakan representasi yang berfungsi sebagai mental model internal atau skema. Keempat, sebagai alat merupakan representasi dapat berfungsi untuk menggambarkan dan mengkoordinasikan dimensi berbeda, tujuan, dan konteks.

\section{Simpulan}

Berdasarkan hasil penelitian ini, maka dapat disimpulkan bahwa penguasaan representasi visual mahasiswa calon guru biologi pada mata kuliah botani phanerogamae masih rendah. Penguasaan representasi visual mahasiswa calon guru biologi dapat dipengaruhi oleh literasi visual, ruang lingkup materi, tingkat representasi materi, dan tipe represe ntasi visualnya.

\section{Daftar Pustaka}

Ainsworth, S. (2008). The Educational Value of Multiple-representations when Learning Complex Scientific Concepts. In Eilam, Billie \& Gilbert, John K. (Ed.), Visualization: Theory and Practice in Science Education(pp. 191-208). London: Springer.

Anagnostopoulou, K., Hatzinikita, V., \& Cristidou, V. (2012). "Pisa and Biology School Textbooks: The Role of Visual Material". Procedia - Social and Behavioral Sciences, Vol. 46. Hal. 1839 - 1845.

Bell, J. C. (2014). "Visual Literacy Skills of Students in College-Level Biology: Learning Outcomes following Digital or Hand-Drawing Activities". The Canadian Journal for the Scholarship of Teaching and Learning, Vol. 12, Hal. 183 -206.

Catley, Kefyn M. \& Novick, Laura R. (2008). "Seeing the Wood for the Trees: An Analysis of Evolutionary Diagrams in Biology Textbooks". BioScience, Vol. 58, No. 10.

Gooding, David(2004). Visualisation, inference and explanation in the sciences. In Malcolm, Grant (Ed.), Studies in Multidisciplinarity, Volume 2: Multi disciplinary Approaches to Visual Representations and Interpretations(1-25). Netherlands: Elevier.

Griffard, P. B. (2013). Deconstructing and Decoding Complex Process Diagrams in University Biology. In Tsui, C. \& Treagust, D. F. (Ed.), Multiple Representations in Biological Education(pp. 165-183). London: Springer.

Halverson, Kristy L. \& Friedrichsen, Patricia (2013). Learning Tree Thinking: Developing a New Framework of Representational Competence. In Tsui, C. \& Treagust, D. F. (Ed.), Multiple Representations in Biological Education(pp. 185-201). London: Springer. 
Harlen, W. (1997). "Primary Teacher' Understanding in Science and its Impact in the Classroom”. Research in Science Education, Vol. 27(3). Hal. 323-337.

Liu, Yang., Won, Mihye, \& Treagust, David. F. (20). Secondary Biology Teachers' Use of Different Types of Diagrams for Different Purposes. In Gilbert, John K., Reiner, Miriam, \& Nakhleh, Mary. (Ed.), Science Teachers' Use of Visual Representations (pp. 103-121). London: Springer.

Mulyani, A.(2014). "Representasi Visual Buku Biologi SMA pada Materi Kingdom Plantae”. Journal Scientiae Educatia, Vol. 3 No. 1.

Prain, Vaughan \& Tytler, Russell (2013). Representing and Learning in Science. In Prain, Vaughan, Hubber, Peter, \& Waldrip, Bruce (Ed.), Constructing Representations to Learn in Science (pp. 1-14). Netherlands: Sense Publishers.

Phillips, Linda M., Norris, Stepphen P., \& Macnab, John S. (2010). Visualization in Mathematics, Reading and Science Education. London: Springer.

Richards, A. R. (2003). "Argument and Autority in the Visual Representations of Science". Technical Communication Quarterly, Vol. 12, Hal. 183-206.

Roth, Wolf-Michael, Pozzer-Ardenghi, Lilian, \& Han, Jae Young(2005). Critical Graphicacy: Understanding Viusal Representastion Practices in School Science. London: Springer.

Schonborn, K. J. \& Anderson, T. R. (2006). "The Importance of Visual Literacy in the Education of Biochemists". Biochemistry And Molecular Biology Education, Vol. 34, No. 2, Hal. 94-102.

Shulman, L. S.(1986). “Those Who Understand: Knowledge Growth in Teaching”. Educational Researcher, Vol. 15, No. 2.,pp 4-14.

Tsui, C. \& Treagust, D. F. (2013). Introduction to Multiple Representations: Their Importance in Biology and Biological education. In Tsui, C. \& Treagust, D. F. (Ed.), Multiple Representations in Biological Education(pp. 3-18). London: Springer.

Vinisha, K. \& Ramadas, J. (2013). "Visual Representations of the Water Cycle in Science Textbooks". Contemporary Education Dialogue 10(1)7-36. 